\title{
Os Processos de Integração Econômica Regional da União Européia e do Mercosul: breve abordagem histórico-evolutiva
}

Leonardo Arquimimo de Carvalho

SUMÁRIO: 1. Introdução. 2. União Européia: conflito e integração. 2.1. O desejo de paz para a Europa: uma abordagem remota. 2.2. Crises e alianças: a Europa de 1890-1914. 2.3. O período entre guerras. 2.4. O pós-guerra e a reconstrução da Europa. 2.5. O Plano Marshall. 2.6. A experiência BENELUXe os momentos posteriores. 3. Mercosul: antecedentes históricos e integração. 3.1. Incidentes da integração latino americana. 3.2. Simón Bolívar e o Congresso do Panamá. 3.3. Novas tratativas, congressos e acordos posteriores. 3.4. O Pan-americanismo. 3.5. Organismos, tratados e associações: elementos recentes da integração latino-americana. 3.6. A integração do Cone-sul: grandes dificuldades a vencer. 4. Elementos distintivos. 5. Elementos de aproximação. 6. Conclusão. 7. Bibliografia.

SUMMARY: 1. Introduction. 2. Union European: conflict and integration. 2.1. The desire of peace for the Europe. 2.2. Crises and alliances: the Europe of 1890-1914. 2.3. The period between wars. 2.4. The postwar and the Europe's. 2.5. The Plan Marshall. 2.6. The BENELUX experience and the subsequent moments. 3. Mercosul: historic and integration. 3.1. Incidents of Latin American Integration. 3.2. Simon Bolivar and the Congress of Panama. 3.3. New treats, congresses and subsequent agreements. 3.4. The Pan-Americanism. 3.5. Agencies, treated and associations: recent elements from the Latin-American integration. 3.6. The integration of the South Cone: difficulties. 4. Distinctive elements. 5. Approach Elements. 6. Conclusion. 7. Bibliography.

Mestre em Relações Internacionais pela Universidade Federal de Santa Catarina(UFSC). Professor de Teoria das Relaçôes Internacionais na Academia de Direito das Faculdades do Brasil. 
SUMARIO: 1. Introducción. 2. El Unión Europea: el conflicto y la integración. 2.1. El Deseo de la Paz para la Europa. 2.2. Las Crisis y las Alianzas: la Europa de 1890-1914. 2.3. El período entre guerras. 2.4. El posguerra y la reconstrucción de la Europa's. 2.5. El Plan Marshall. 2.6. La experiencia de BENELUX y los momentos subsiguientes. 3. Mercosul: histórico y integración. 3.1. Los incidentes de la Integración Latinoamericana. 3.2. Simón Bolívar y el Congreso del Panamá. 3.3. Los congresos y los acuerdos subsiguientes. 3.4. El PanAmericanismo. 3.5. Los Organismos, tratados y las Asociaciones: los Elementos Recientes de la Integración Latinoamericana. 3.6. La integración del Cono del Sur: dificultades. 4. Los elementos distintivos. 5. Elementos de la Aproximación. 6. Conclusión. 7. Bibliografia.

RESUMO: Em um breve resgate histórico, o ensaio apresenta os caminhos percorridos pelos povos - europeus e latinoamericanos - até alcançar a integração. Apresentam-se as diferenças e semelhanças marcantes entre os processos integracionistas do Mercosul e da União Européia, bem como as influências politicas e economicas que impulsionaram o desenvolvimento regional.

ABSTRACT: In a brief historical rescue, the essay presents the parts traveled by Europeans and Latin Americans until reach integration. It also presents the differences and the similarities between Mercosul's integration process and European Union's, demonstrating political and economic influences that urged regional improvement.

RESUMEN: El ensayo presenta las partes viajadas por las personas - los europeos y los latinoamericanos - hasta el alcance la integración. También presenta la diferencia y la similitud entre la integración de proceso del MERCOSUR con la Unión Europea. Los dos ellos tienen influencias politicas y económicas que auxiliaran el desarrollo regional. 
PALAVRAS-CHAVES: Mercosul. União Européia. Integração regional. Influência política e econômica.

KEY-WORDS: Mercosur. European Union. Regional integration. Political and economic influences.

PALABRAS-LLAVES: MERCOSUR. Unión EuTopea. Integración regional. Influencias políticas y económicas.

\section{Introdução}

De modo elementar poder-se-ia afirmar que a integração regional corresponde a um processo ou estado onde diversas naçôes decidem formar um grupo, com os mais diversos objetivos. Tratando-se de um meio e não de um fim, sendo, contudo, apresentado como implementadora do desenvolvimento econômico. Contemporaneamente os escopos econômicos têm sido manifestados de modo mais significativo.

No periodo posterior a Segunda Guerra Mundial, o comércio internacional encontrou várias nuanças para o seu crescimento, do bilateralismo ao multilateralismo, passando pelo regionalismo. De qualquer forma, ganha força o integracionismo econômico - de modo geral, valendo-se do regionalismo - como instrumento de crescimento econômico.

Logo, a integração regional, tem sido apontada, como viés à superação das muitas dificuldades que afligem o Estado moderno. A principal delas, relacionada ao aspecto econômico, assim, criar um espaço para o desenvolvimento e para inserção competitiva dentro do mercado mundial, criando escudos para os danosos efeitos causados pelo darwinismo nas relações econômicas internacionais.

As vantagens de um processo integracionista, mesmo que unicamente com tonalidades econômicas são inegáveis, e grande parte dos blocos em formação já tem consciência deste ganho. Alguns processos têm sido conduzidos com compromissos mais sérios e definitivos, com a criação de estruturas com poder decisório e independência necessários para o alavancamento integracionista. Enquanto outros são conduzidos de maneira cautelosa, sempre dependendo de circunstâncias econômicas momentâneas. 
Muitos dos processos de integração regional buscam inspiração no modelo europeu, hoje aperfeiçoado sob a denominação de União Européia (UE); onde o adiantado grau de compatibilização das inúmeras políticas dos países membros por intermédio das forças supranacionais é demasiado impressionante.

Uma pergunta, contudo, parece surgir sempre que são estabelecidos elementos de comparação entre os diversos processos integracionistas principalmente se a comparação é realizada entre a UE e outros processos incipientes -, qual seja, em que medida os fatos conformadores da história européia são determinantes na postura adotada por aqueles países na condução da sua integração regional? No trabalho de construção e legitimação do Mercado Comum do Sul (Mercosul), a observação do modelo mais adiantado é uma constante, e a pergunta também palpita.

Neste sentido, pretende-se discutir a evolução histórica dos processos de integração na Europa e na América Latina, observando alguns fatos históricos mais contundentes e capazes de estimular ou não o seguimento do trabalho integrador. Busca-se ainda, encontrar elementos de dissensão e o de similitudes entre UE e Mercosul.

Para tanto, num primeiro momento, objetiva-se analisar o contexto histórico em que nasce o crescente processo de união dos povos europeus, fazendo uma abordagem remota do desejo de paz no Continente europeu, ainda, recordando o período de crises e alianças que antecederam a Primeira Guerra Mundial, o período entre guerras, a Segunda Guerra Mundial, e o pós-guerra.

Num segundo momento - ainda que de maneira perfunctória, como ocorre no momento anterior -, busca-se analisar as raizes mais profundas do Mercosul com os antecedentes da integração latina americana, dando atenção à figura emblemática de Simón Bolívar e o Congresso do Panamá de 1826, e as negociaçōes posteriores intentadas sob novas óticas, além do Pan-americanismo e elementos recentes da integração latina americana dando relevo substancial ao Mercosul.

Posteriormente apresenta-se um clemento distintivo principal entre os processo de integração européia e mercosulina, responsável, numa visão simplista, por muitas das dessemelhanças e disparidades entre os blocos analisados. Um elemento procedimental ou instrumental, secundário, porém, não menos importante, será também apontado como diferenciador entre as formas de condução do processo.

Ao final, pretende-se arrolar alguns elementos que demonstram a proximidade nos objetivos e motivos integracionistas entre os dois blocos regionais tais como o período, os objetivos desenvolvimentistas, reflexos 
da política internacional e principalmente estancamento do poderio político-econômico dos norte-americanos.

\section{União Européia: conflito e integração}

A observação dos antecedentes históricos da União Européia implica necessariamente a limitação temporal do período em que se pretende centrar atenção, já que a amplitude da abordagem poderia resultar estéril em face da quantidade dantesca de elementos minimamente decisivos na construção de uma nova sociedade européia.

Não acarreta em prejuízos, contudo, uma ligeira retrospectiva que de qualquer maneira fornece os rudimentos à compreensão do evolver dos fatos na direção de um consenso de difícil estruturação, qual seja, a formação concentrada de Estados sob o poder de um cetro supranacional.

Aidéia da criação de uma Europa em imandade com seus povosvivendoem harmonia, constantemente freqüentou a idéia de pensadores, políticos e poetas, se não vejamos.

\subsection{O desejo de paz para a Europa: uma abordagem remota}

Segundo Casella, remonta ao Cristianismo medieval ou mesmo até à antigüidade a noção de unidade espiritual e cultural, concomitante ou não, às tentativas de união política dos povos que habitavam o território europeu.

Apesar das divergências, um elemento comum permeava a idéia de união dos povos europeus, a necessidade de fortalecer a defesa contra os inimigos externos, geralmente determinadas por conveniências passageiras e incidentais, v.g. a ameaça muçulmana. Naqueles períodos, a elaboração de ensaios buscando um norte ao continente encontrava fundamentação preponderantemente na formação de uma comunidade cristã.

São exemplos, Dante Alighieri no início do século XIV, em seu tratado, De Monarchia, que sonhava com uma polis christiana. Contemporâneo de Dante, Pierre Dubois, conclamava os europeus à reconquista da Terra Santa e do Santo Sepulcro - Reconquista da Terra Santa de 1306 - além da pacificação da Europa, trabalho atribuído à França em substituição a liderança que pertencera ao Sacro Império Romano Germânico. Erasmo de Roterdão Lamento da paz de 1517 - propalava idéias de uma européa República dos sábios, contrária a guerra e favorável a paz e a concórdia, tranquillitas orbis Christiani. ${ }^{2}$

CASELLA, Paulo Borba. Comuniade enropén e seu ordenamento juridico, p. 58

Idem, p. 60-1. 
Certamente, as manifestações produziram efeitos já que a religião cristã havia conquistado um espaço significativo em toda a Europa. Tratandose de um importante instrumento de propalação da sua doutrina.

Num segundo momento desta observação histórica remota, de modo mais nítido, surge um novo elemento motivador da unidade, a paz pela paz, influencia do periodo iluminista. Eméric Crucé já na idade moderna, apontava as guerras como resultado das rivalidades dinásticas, da políica de poder dos diferentes príncipes, idealmente refletia sobre uma Europa unida ou federada. William Penn, em sua obra, Ensaio sobre a paz presente e futura da Europa de 1692, do mesmo modo apregoava o pacifismo. Abbé de St. Pierre - Le projet de la paix perpétuelle de 1713 - conhecido como advogado da República Européia -, propunha um projeto de paz perpétua para Europa, influenciando toda uma geração até o século XX.

Kant com a mesma argumentação editou seu ensaio filosófico sobre a paz perpétua - Zum Ewigen Frieden - apresentava propostas realistas, demonstrando que os monarcas tendiam à guerra por que consideravam os Estados patrimônios seus. Almejava, no texto clássico, uma federação universal, formada por leis que considerava fundamentais para obtenção da paz. ${ }^{4}$

Vitor Hugo e Emile Zola, dentre outros destacados escritores, reforçavam o movimento humanista em direção à integração ${ }^{5}$. Em verdade, o ideal dos pensadores ainda estaria longe de refletir um anseio dos governantes, e o século seguinte marcaria para sempre a história européia, obrigando-os a restabelecer os ensinamentos propalados pelos pensadores.

\subsection{Crises e alianças: a Europa de 1890-1914}

Possivelmente no decorrer do século XX ocorreram os lances principais da formação comunitária européia, que gradativamente ganharam força na medida que incorporaram novos elementos de legitimação. A importância das guerras neste contexto, não permite uma abordagem que não as mencionem.

Neste sentido, as alianças estabelecidas no período anterior a Primeira Guerra eram manifestamente formadas com o objetivo de aumentar o poder e fortalecer as defesas na hipótese de um conflito eminente, que circulava entre fronteiras quentes ${ }^{6}$. Os novos Estados constituídos ansiavam

\footnotetext{
Idem, p. 61-3.

KANT, Immanuel. A paz perpétua, p. 25-40.

OLIVEIRA, Maria Odete de. União Européa: processos de integração e mutação, p.84.

"Alemanha é França continuavam discutindo em funçăo da Alsácia-Lorena, França e Itália travam guerta aduaneira. França tentava acordar com Inglaterra em relaçäo à s colônias africanas. Rússia e Inglatera estiveram na eminência de um conflito en funço das colonias na Ásta. Russos e frunceses haviam furmado alianç secreta defensiva contra a Alemanha, ambos tinham interesses comuns que era de teduzir o poderio ingles. A Inglaterra ressentiase pelo fato de ter surgido uma nova tival - Alemanha - maritima, colonial, industrial e comerial.
} 
por mais poder enquanto os velhos - Império Austro-húngaro e Otomano - lutavam contra grupos nacionais.

Durante o período compreendido entre 1905 e 1914 ocorrem cinco grandes crises gradativamente mais sérias, originadas de duas grades crises: entre franceses e alemães de origem colonial, e austríacos e russos de origem balcânica ${ }^{7}$. A quinta crise, de julho de 1914, desencadeada pelo assassinato do herdeiro arquiduque Francisco Ferdinando, ocasionou o desenlace de todos os acordos e alianças firmados no decorrer dos anos. A Guerra cra uma questão de tempo.

Nas primeiras décadas do século $\mathrm{XX}$, no auge do imperialismo tanto a pretensão alemã quanto à britânica e francesa era de um status global único e o objetivo de guerra resumia-se na aniquilação do outro, com vitória total: um objetivo tresloucado que acabou por destruir vencidos e vencedores, conduzindo os derrotados para a revolução e os vencedores à bancarrota e à exaustão fisica. A Inglaterra, exemplificativamente, jamais voltou a ser a mesma depois de 1918 , arruinará a sua economia, gastando o que não possuía. ${ }^{8}$

Apesar de significativa a quantidade de alianças e acordos firmados no período indicado, nenhum deles objetivamente pretendia estabelecer alianças para a paz e o desenvolvimento. Ao final, a paz imposta como retribuição aos perdedores, que objetivava controlar a Alemanha e redefinir as fronteiras do império russo, habsburgo e otomano; revelou-se um dos estopins do novo conflito mundial.

De qualquer maneira os elementos recordados são responsáveis pela desestruturação

A primeita crise foi a marroquina, provocada por um discurso de Guilherme II no ano de 1905 , que prometet proteger a independência de Marrocos, contrariando os interesses franceses que, desce 1900, por intermódio de sucessivos acotdos con Itália, Grä-Bretanha e Espanha, buscava estabelecer ali um protetorado.

A segunda é a da Bósnia-Herzegovina de 1908-1909. O Imperio AustroHủngaro almejava destruir a Servia, mas as tentativas cconômicas não resultaram exitossas. Como a propaganda Servia era forte na Bósnia-Herzegovina aqueles resolveram anexar este teritótio nominalmente turco. Os sérvios protestaram e peciram ajuda aos russos, que detinham un exército fraco e setiamente avariado em funçäo da aniquilação conduzida pelos japoneses na Manchúria, cntão, os russos pediram ajuda aos franceses, que não desejavam uma guerra nos Bálcäs.

A crise conseqüente é novamente marroquina. Imperava ptofunda desordem em todo Marrocos, sendo confiado à França a policia dos principais portos do país - recebera a incumbência em 1906, após a primeira crise, durante a conferencin de Algerisas, quando a idéa de internacionalização do território marroquino, defendida pela Alemanha, fora descartada. Em abril de 1911, o sultăo Hafid, encontrava-se cercado por rebeldes, tendo pedido ajuda aos franceses estes năo hesitaram em enviar tropas para o interior do país. Alemäes protestaram colocandio uma canhoneira no porto de Agadir. Russos deram troco a França negando apoio contra alenães, ingleses receosos com o poderia naval alemão incentivam acordo. Resultou pois, num grande acordo colonial francoalemaro, que liquidou as desałenças coloniais entre os dois páses.

A quarta é novanente una crise nos Bálcãs. O Impétio Otomano desmoronava na Europa, já havia perdido, Grécia, Sérvia, Romenia, Montenegro, Bulgária, Rumélia Oriental, Bósnia-Herzegovina. Bulgária, Sérvia e Grecia desejam o restante do territóno turco europeu, formaram aliança, e derrotaram turos em poucos dias. Bulgaria tinha pretensão maior e näo hove acordo na divisão do espólio, atacata sérvios é fora derrotada em quinze dias. Austria-Hungria pretendia apoiar butgaros, mas Alemanha a desanimou. In: DUROSELLE, Jean Baptiste. A Europa de 1815 aos nossos dias wida politica e relagoes intemacionas, $\mathrm{p} .4958$.

"HOBSBAWM, Enc. Era dos exiremos: o breve século XX: 19141991, p. $36-8$. 
do período seguinte que, por sua vez, serão decisivos na construção de instrumentos para evitar novos conflitos, formando uma comunidade em torno do ideal de paz.

\subsection{O período entre guerras}

No período entre guerras, registra-se a ação de alguns homens que dedicaram esforços com vistas a realizar a unificação dos Estados europeus e que impulsionaram o processo. Dentre eles, Richard CoudenhoveKalergui - Conde de Coudenhove-Kalergui - destacou-se como um dos grandes precursores do processo. Conceptor do Paneurepésmo, acreditando-se ser este o meio apropriado para evitar a penetração dos soviéticos e o domínio econômico dos norte-americanos.

Em 1924, Coudenhove-Kalergui obteve na forma de uma associação apoio para seu ideal, formando a União Pancuropa. Para presidir os Conselhos Nacionais da União Paneuropa importantes personalidades políticas e culturais foram chamadas, dentre elas Hjalmar Schacht, Konrad Adenauer, Yvon Delbos, Edouard Herriot, Conde Sforza, Paul Claudel, Paul Valéry, Erich Maria Rilke, Ferrero e Miguel de Unamuno. O presidente de honra do movimento era o político francês Arístides Briand."

Briand foi outro importante personagem. Sob sua tutela, as idéias paneuropeístas alcançaram o status de único intento de grande envergadura realizado oficialmente no período entre guerras, com objetivo de unir os países europeus. Em setembro de 1929, explicou sues objetivos paneuropeus à Sociedade das Nações (SDN); em maio de 1930, enviou para os membros da SDN um amplo documento, contendo seu projeto $^{10}$. Porém, o agravamento do protecionismo, conseqüência da Grande Depressão, acrescido da morte do Chanceler alemão Stressemann - entusiasta da proposta da união européia -, o crescimento do ideal nacional-socialista na Alemanha, além da guerra subterrânea promovida pelos britânicos contra a união da Europa continental contribuíram para o insucesso inicial da proposta. Na SDN, contudo, estabeleceu-se um debate em tomo do tema, criando um grupo de estudos à temática, sob a direção de Briand. Com a morte deste em 1932, gradualmente os trabalhos do grupo perderam forças, tendo sido encerados em 1937.

Num cenário mais pragmático, muitos paises europeus rumavam à conflagração. A instabilidade no período posterior a Primeira Guerra Mundial marcada pelo colapso generalizado nas relações entre muitos países - vinte anos de crise - criaram um ambiente de hostilidades onde um conflito de grandes proporções parecia sempre presente. ${ }^{11}$

\footnotetext{
"TAMAMES, Ramón. La Unión Européa, p. 4-5.

10 Idem, p. 5 .

11 De modo contráno, em 10 de dezembro de 1931, Lord Cecil disse à Assembléa da LDN, que dificimente teria havido un periodo ma históna do mundo en que a guerna parecesse täo pouco provávé quanto aquele em que viviam, Apud

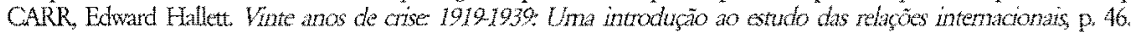


Tal afirmação é manifestada na invasão da Manchúria pelo Japão, em 1931; da Etiópia pelos Italianos, em 1935; na intervenção alemã e italiana na Guerra Civil espanhola; na invasão alemã da Áustria, no início de 1938, e ocupação da Checoslováquia nos anos de 1938 e 1939; no pacto entre Hitler e Stalin em agosto de 1939; na ocupação da Albânia pela Itália no mesmo período e nas exigências alemãs à Polônia; além das omissões da SDN contra Japão e Itália; a não-reação da França e Inglaterra à denúncia unilateral da Alemanha ao Tratado de Versalhes, principalmente em relação a reocupação da Renânia em 1936; também a não-reação em relação à Guerra Civil Espanhola, e à invasão da Áustria, eram todos fatos que criavam um ambiente de animosidades, tornando explosiva a relação entre os diversos países naquele período. ${ }^{12}$

Provocavam ainda, tais fatos, grande instabilidade, sendo portanto inevitável um acordo para assegurar a não ocorrência da guerra. Estes foram firmados, mas tinham objetivos diversos da paz e eram integrados às estratégias de guerra dos países em eminência belicosa. ${ }^{13}$

Por outro lado, não fora estéril o período entre guerra. O surgimento da união econômica entre Bélgica, Luxemburgo e Países Baixos e o movimento Paneuropeu, constituíam-se em semente de uma idéia que mudaria o Continente europeu para sempre.

\subsection{O pós-guetra e a reconstrução da Europa}

Até a Segunda Guerra Mundial, a Europa estava condicionada a olhar para além das fronteiras, somente com o fim da hegemonia européia e a emergência de novas potências é que se aposta na integração. Os antigos desejos de unificação conseqüentemente ganharam força, já que as economias estavam destruídas e os despojos de guerra eram disputados entre Estados Unidos e União Soviética. ${ }^{14}$

Em setembro de 1946, Churchill, propõe a criação dos Estados Unidos da Europa, proposta que teve grande impacto em face do desejo de paz e da necessidade de uma reestruturação econômica.

12 HOBSBAWM. Op, cit, p. 4445.

13 Para Hobsbawm, a expansão imperialista e suas contradiçoes foram às causas historicas subjacentes da Segunda Guerra Mundial, tendo sido a Alemanha e uma determinada classe dirigente alemã apoiando Adolf Hitler que a causou. "Em termos tnais simples, a pergunta sobre quem ou o que causou a Segunda Guera Mundial pode ser respondida em duas palawras: Adolf Hitler". In: HOBSBAWM. Op. cit. p. 43.

i THORSTENSEN, Vera. Comunidade Européta a construção de una potência económica, p. 31.

15 "Debemos crear un germen de Estados Unidos en Europai Por qué no podria existir una agrupacion europea, que daría un sentido de patriotismo más grande y de ciudadania comín a los pueblos de este poderoso continente? $Y_{x}$ por qué esta agrupación no habría de ocupar el lugar que le corresponde entre lás demás agrupaciones? CHURCHILL, Winston apud. TAMAMES. Op. cit., p.7. 
Três momentos podem ser notados como decisivos para o processo de origem e institucionalização das Comunidades Européias: o primeiro, refere-se ao Congresso de Haia de 1948, organizado pelo Conitê de Coordenação dos Movimentos para Unificação Européia ${ }^{16}$, o segundo a criação do Conselho Europeu através do Tratado de Londres de maio de 1949, o terceiro momento, considerado o mais significativo, a declaração do Ministro francês de Assuntos Exteriores, Robert Schuman, em maio de 1950. ${ }^{17}$

Os dois primeiros momentos apontados como fundamentais, correspondem à eleição de uma estratégia para a condução do processo de engendramento da primeira das unidades européias, por intermédio de instrtuições políticas de ideologias comuns. ${ }^{18}$

Ao final do Congresso de Haia adotaram-se diversas resoluções, dentre elas, a proposta para a criação de uma comunidade econômica e política. A constituição de um comitê de estudos da Comunidade Européia foi decidida em face da ressonância que teve o Congresso. Seu primeiro trabalho foi analisar as propostas de organização de uma Assembléia Parlamentar Européia - franco-belga - ou de um Conselho Intergovernamental de Ministros Europeus - inglesa. ${ }^{19}$

O Conselho da Europa era formado por um Comitê de Ministros e uma Assembléia consultiva. Os britânicos eram contrátios a outorga de efetivos poderes para o Conselho, contudo, não era o único problema já que carecia de funções específicas. ${ }^{20}$

Os projetos políticos da unificação européia do período anterior a Segunda Guerra Mundial bem como o Conselho da Europa resultaram em fracassos e frustrações, o que não ocorreu com os projetos de cooperação construídos sob uma ótima econômica. A Declaração de Schuman - como ficou conhecida - também apontada como elemento importante, inovou ao elencar um norte inicial sobre o qual a unidade deveria ocorrer, qual seja, a integração econômica e o estabelecimento de bases comuns de desenvolvimento econômico. Foi além ao demonstrar que somente em função de realizações concretas poderia haver avanços, sendo que a superação da rivalidade entre França e Alemanha deveria ter início imediatamente. ${ }^{21}$

\footnotetext{
in Tratava-se de uma associação de europeistas formada pelas Chated Europe Movencht, European Union of Federalists, Liga Europea de Cooperación Econónica, posteriormente a associaçấo passon a chamar-se "Movimento Europeu", mesmo movimento responsável pelas importantes conferências de Westminster. Idem, Ibidem.

HONRUBIA, Victoria Abellán. In: HONRUBIA, Victoria Abellán. COSTA, Blanca Vilà (org.) Leci ones de Dercho Comunitatio Europeo, p. 14.

13. Congresso de Haia apontava à fómula da união ou federação dos Estados europeus, encuanto o Conselho da Europa surgia como uma organização internacional de cooperação política entre os Estados, ideologicamente o Conselho da Europa frrmava em seu preâmbulo "o respeito aos valores spirituais e morais comuns aos povos que são a onigem dos principios da liberdade individual, da liberdade politica e da preeminência do direito, sobre os quais se funda a democracia". Idem, p-14-5.

19 TAMAMES Op. cit, p. 7.8.

20. Idem, ibidem.

21 HONRUBIA, Op. cit. p. 14-5.
} 


\subsection{O Plano Marshall}

Versalhes não obteve méritos ao deslocar seus objetivos à humilhação dos derrotados; a retribuição imposta aos perdedores da Primeira Guerra Mundial conduziu a Alemanha ao nacionalismo socialista e ao sentimento revanchista.

As instituições Bretton Woods, de modo contrário, representavam uma alternativa as tradicionais compensações de guerra, já que teoricamente, fundadas com o objetivo de reconstruir a economia do pós-guerra. Com tal intento, surge no pós-guerra o Plano Marshall que abriu caminho para a rápida reconstrução da Europa, onde o Estados Unidos incentivava a reconciliação e o compromisso com a integração econômica ${ }^{22}$; mesmo não integrando "[p]arte do planejamento econômico do pós-guerra, mas que veio a ser implementado tanto por razões econômicas, como pela urgência política representada pela ameaça comunista em diversos países do continente europeu." 23

Os norte-americanos sensivelmente preocupados como o avanço soviético iniciaram seu plano de contenção como base na Doutrina Truman e no Plano Marshall. Os soviéticos em contrapartida montaram um sistema de cooperação econômica conhecido como Plano Molotov. Dentre as condições exigidas pelos administradores do Plano Marshall estava o estabelecimento de um programa conjunto de reconstrução, que deveria ser estabelecido no âmbito do Comitê de Cooperação Econômica Européia. Este comitê de modo eficaz elaborou estudos demonstrando que união alfandegária poderia contribuir para prosperidade da Europa. Do comitê surge em 1948 a Organização Européia de Cooperação Econômica (OECE), que serviu de base para o surgimento da OCDE. ${ }^{24}$

A solução encontrada foi inegavelmente perspicaz, ao final da Segunda Guerra Mundial havia restado muito pouco em termos econômicos, toda estrutura da economia européia estava destruída. A ausência de recursos materiais bem como de recursos financeiros, os compromissos monetários significativos assumidos com os norte-americanos no curso da guerra, acrescidos das reparações devidas pelos perdedores, criavam

\footnotetext{
22 "The Marsiall Plan paved the way for a rapid rebulding of Europe, where the United States cacounged reconciliation and a commitment to economic integration". AMIN. Op. cit, p. 26.

33 ALMEIDA. Op. cit, p. 55.

2. Idem, p. 55-7.
} 
um ambiente de fragilidade onde os países dependiam do auxílio externo para reconstruir suas economias.

A ajuda poderia ser obtida ou dos norte-americanos ou dos soviéticos, os países da Europa Ocidental optaram pelo auxílio dos primeiros, enquanto os do Leste Europeu "optaram" pela ajuda soviética. A opção pela ajuda norte-americana foi fundamental para construção das Comunidades Européias, não sendo outra a conclusão de Jean Monnet. ${ }^{25}$

\subsection{A experiência BENELUX e os momentos posteriores}

Desde 1922, Bélgica e Luxemburgo mantinham uma união alfandegária. Ao final da Segunda Guerra Mundial os Países Baixos somaram-se a Bélgica e Luxemburgo. Em janeiro de 1948, a Convenção BENELUX estabeleceu a entrada em vigor de uma União Aduaneira entre Bélgica, Luxemburgo e Países Baixos. Estes países pretendiam criar um território econômico com livre circulação de bens, serviços, capitais e pessoas, eliminando qualquer discriminação entre produtos e produtores nacionais respectivos, instaurando uma política econômica e uma política externa comum, dentre outras ações ${ }^{26}$. Lembra Oliveira que a Convenção BENELUX estabelecia quatro etapas evolutivas até "[a] supressão das restrições do comércio, o estabelecimento de tarifas comuns e a paulatina liberação da mobilidade de fatores de produção, contemplando a formação de uma união econômica, objetivo difícil de atingir, o que motivou os países-membros do BENELUX procederem negociações junto ao Tratado de constituição da Comunidade Européia do Carvão e do Aço (CECA)". ${ }^{27}$

Com os resultados positivos alcançados em pouco tempo, e o aumento significativo no comércio intra-BENELUX, os paises-membros consideravam cumpridas grande parte das pretensões do acordo. Tendo a experiência servido como extrato para os ulteriores processos de integração conduzidos no âmbito europeu.

\footnotetext{
25. Desde el Plan Marshall y el Lan Schuman, el apoyo americano para la union de Europa, jamás há disminuido. Puedo testimoniar aqui mi propha experiencia de que este apoyo ha sido el mís grande valor en la acción que nos ha conducido al punto a que hernos llegado en la unificación de Europa. Por primera vez en la Hisronia, el pais mís poderoso del mundo ha ajudado a otros a nairse, en lagar de seguir la vieja míximal de divde y wencerás. MONNET, Jean. Europe-Anérique, relations de partenaires necessuriss ia la pux. Apud. TAMAMES. Op cit, p. 12.

ALMEIDA. Op. cit. p. 57.

3 OLIVEIRA. Uniăo Européa: processos de integracăo e mutagato, p. 85-6.
} 
Neste contexto surgiu a idéia de integrar a produção franco-alemã de carvão e o aço, o que acabou resultando no Tratado de Paris de 1951, e conseqüentemente na Comunidade Européia do Carvão e do Aço $(\mathrm{CECA})^{28}$, celebrado entre Alemanha, França, Itália, Bélgica, Luxemburgo e Países Baixos, objetivava uma melhora no nível de vida dos membros, por intermédio da criação de um mercado comum, e com a eliminação de restrições ao comércio do carvão e do aço, superando as práticas discriminatórias, representava o nascimento da Comunidade Européia. ${ }^{29}$

Em 1955, os representes dos países membros da CECA, reunidos na cidade de Mesina discutiram a possibilidade de ampliar a experiência obtida no setor econômico do carvão e aço para o setor de energia nưdear, e para as demais atividades econômicas.

Os momentos posteriores foram desencadeados de forma sucessiva, tendo sido criadas pelos Tratados de Roma de 1957, a Comunidade Econômica Européia (CEE) e a Européia de Energia Atômica (CEEA), nascidas da ausência de acordo em relação à Comunidade Européia de Defesa (CED) proposta em 1952 - inspirada na situação política militar do período - e do Relatório Sppak ${ }^{30}$. Ainda, os tratados posteriores que ampliam a abrangência dos Tratados Marcos, são o Tratado de Fusão dos Executivos de 1965, o Tratado Ato Único Europeu de 1986, o de Tratado de Maastricht de 1992 e o de Amsterdam de 1997.31

Gradualmente, cada um desses tratados vai tornando mais amplos os objetivos da União Européia. O grau de complexidade das decisões e das suas interdependências apontam para um dificil retrocesso.

De qualquer maneira, apesar das grandes dificuldades enfrentadas pelas Comunidades Européias, os cronogramas e as metas têm sido alcançados a cada novo desafio de forma surpreendente, suscitando o questionamento sobre as diferenças com os demais processos de ação concertada, e o motivador dos descompassos entre os graus do coeficiente de integração. ${ }^{32}$

\footnotetext{
2s Na ótica de Amin, a CECA, ben como outras instituiços desenvoivimentistas europélas, decomiam do interesse estrategico norteameticano. The Markall Plan pared the way for a tapid rebuilding of Europe where the United States encoumged reconciliation and a commitment to economic integration. The Organization for Europezt Economic Cooperation was ceated, which became the Organization for Economic Cooperation and Development OECD in 196\%; it was followed by the Council of Europe in 1949, the European Cod and Steel Conmunity ECSCI in 1951, and the Theaty of Rome in 1957. These bodies were not concerved to bulld a Europe able to compete with the United States and achnere autonony, but to create a subsystem of an open worldwide system necessary for US hegenony. In. AMN, Samir. Re-rewing the postwar pertolt an intellectual ituerary, p.26.

2) OLVEIRA. Uniño Furopéta processos de integraço e mutarâa, p. $93-5$.

EUROPA. Op. cit. p. 108

5. OLVLIRA. Unia Européa processos de integracio e mutacio, p. 83.

3. O coeficente de integtryato diz texpeto à troa comercil entre os paises que formam um bloco como a percentagen do comécio

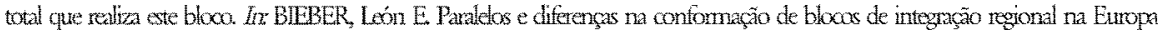

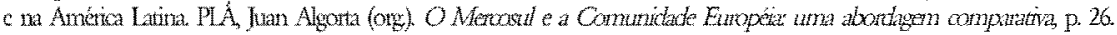




\section{Mercosul: antecedentes históricos e integração}

A temática aqui proposta, pode ser apresentada, dentro de dois enfoques. ${ }^{33} \mathrm{O}$ primeiro, partindo de elaboração única e exclusiva das relações de rivalidade entre Argentina e Brasil, já que sem dúvidas, suas relam ções são o germe para o desenvolvimento de um pretenso mercado comum do sul. A segunda, firma-se no marco principal da figura de Simón Bolívar e de seus ideais, quiçá em alguns elementos anteriores do desejo de integração dos países americanos. Deste modo, cuidando de uma maneira mais generalizada do tema Mercosul, parte-se de um enfoque centrado na evolução temporal das tentativas de formar uma integração latino-americana.

Mesmo, incorrendo-se na possibilidade de tornar a análise lacunosa, necessária se faz, a opção por uma abordagem mais ampla, fazendo alusão as duas frentes, por estabelecerem um melhor entendimento, sobre a trajetória da formação de blocos regionais de integração da América Latina.

\subsection{Incidentes da integração latino americana}

Como antecedentes da independência hispano-americana são geralmente apontados os ideais liberais do século XVIII, a independência dos Estados Unidos, a Revolução Francesa e a tomada da península ibérica por Napoleão. $O$ desejo de liberdade na América hispânica foi pensado como resultado da união dos diversos núcleos de colonização espanhola. A irmandade lingüística e cultural contribuía à formação de espaços comuns de reivindicações, ainda, of fato de serem todos expropriados pelo mesmo senhorio tinha efeito semelhante.

No período que antecedeu o Congresso do Panamá de 1826 - marco inicial do desejo latino americano de construir uma liberdade concertada contra os grilhões das metrópoles - alguns expoentes manifestavam suas teorias sobre o assunto, ocasionalmente estas idéias estavam ligadas à própria vontade da Coroa. O ideal da formação de uma união americana do ponto de vista de sua existência não é tão recente, foi pela primeira vez

\footnotetext{
${ }_{33}$ Outro antecedente ainda mais renoto é relatado por Galvez, que lenbra que os powos indigenas não conheciam fronteiras, e que auriliados pelos jesutas, integraman toda a Bacia do Prata, realizando uma integraço cultural e econômica etn perólos remotos. GALVZ, Lúcha Las misiones jesuiticas entre los guaranies: primer intento de integración regional. Apud. JAEGER JUNIOR, Angusto Mercosil e a five circulação de pesoas Florianopolis, 1999. Dissertaça de Mestrado. Universidade Federal de Santa Catarina, p.12.
} 
explicitado em 1791 pelo venezuelano Francisco Miranda. Este desejava estruturar um país continental, que abarcaria toda a América Latina e Central até o Mississipi, ou do Mississipi até a Patagônia, chamaria Colômbia. ${ }^{34}$

Em 1810, Pedro Vicente de Cañete propusera um sistema federativo continental na forma de uma regência soberana, composta por quatro vice-reinados em representação a Dom Fernando VII. No mesmo ano, o peruano Juan Eganã anunciava a necessidade de unir os povos de origem espanhola. Ambos defendiam interesses da coroa hispânica, como também o fazia o argentino Juan Martínez de Rozas. ${ }^{35}$

Ainda em 1810, o Chile publica a Declaração do Povo Chileno, onde considerava fundamental a união dos povos latinos com objetivo de defenderem suas soberanias. ${ }^{36}$

Mariano Moreno, opositor das idéias até então apresentadas, desejava a desvinculação dos países latinos das monarquias européias. Tratava-se de um período conturbado em que os países latinos permaneciam lutando por suas independências. ${ }^{37}$

Certamente que a figura mais forte dentro da história independentista latino-americana seja a de Simón Bolívar. Trata-se de uma figura enigmática, mito que ultrapassou o homem. Os inúmeros documentos arquivados de seu punho demonstram que Bolivar guardava as qualidades de político perspicaze progressista, estrategista bem informado e astuto, enciclopedista e literato. ${ }^{38}$

\footnotetext{
4 ARNAUD, Vicente Guillermo. Mercosur - Unión Europea, Nafta y los procesos de integración regionat. p. $30-9$.

3." Idem, ibidem.

3 Trecho da "Declaraça do Povo Chileno": El dia en que la América reunda en un Congreso se de los dos continentes, sa solo de Sud, hablará al resto de ta Tierra, su voz se harâ respetar y sus resoluciones seran dificilnente contradichas. Idem, p. $37-8$.

${ }^{37}$ Idem, p. 30-9.

${ }^{3}$ No es oute haya dos Congresos. Cóno fomentaráti el cistra los que más conocen la neceridad de la unión? Lo que queremos es que esa unión sea efectiva, para animanos a la gloriosa empresa de nuestra libertud. Unimos para reposar y dormir en los brazos de hapala, ayer fue mengia, hoy es una traxión. Se discute en el Congreso nacional lo que debiera estar decidido. Y, ¿qué dicen? Que deberiamos empezar por una Contederacion: jomo si todos no estuviesemos confederados contra la tiranía extranjera! Que debemos esperar los resultados de la poltica de Espafia: qué nos importa que Espana venda a Bonaparte sus esclaros, o que los conserve, si estamos resueltos a ser libres? Esas dudas son triste efecto de las antiguas cadenas. $Q$ Que los grandes proyectos deben prepararse con calma! Trescientos años de calna, ino bastani ${ }^{2}$ Se quieren otros trescientos todava? La Junta Patriotica respeta, como debe, el Congreso de la nactón; pero el Congreso debe oí a la lunta Patritia centro de luces y de todos los intereses revolucionarios. Pongamos sin temor la piedra fundanental de la libertad sudamericana. Vacilar es perdemos. Propongo que una comisión del seno de este cutpo lleve el soberano Congreso estos sentimientos. BOLIVAR, Simón. Discurso proferido junta à Sociedad Patrítica de Caracas em 3 de Junho de 1811. In: Mondolf, Edgardo (comp.). Bolivar, Ideas de un Espixitu Visionario. Apud http: /wekker.seagull.net/discursos,htmi; onde também, podem ser obtidas informações sobre pensamentos, cronologia, árvore genealogica, biografias, discursos, prodamas e escritos de Bolivar.
} 
Bernardo Monteagudo, outro libertário, produziu em 1824, o Ensaio sobre uma Confederação Continental, onde afirmava que a independência seria o primeiro interesse do Novo Mundo, assinalando o perigo que representava o Gabinete Imperial no Rio de Janeiro, servindo à Santa Aliança. ${ }^{39}$

\subsection{Simón Bolívar e o Congresso do Panamá}

Em setembro de 1815, Simón Bolívar redigiu a Carta da Jamaica. Representava manuscrito importante, que pretendia delimitar o caminho para as Américas. Nela estavam contidos os desejos e as dificuldades da integração da América Hispânica. ${ }^{40}$

O importante documento não pretendia a unidade política-institucional, mas a agregação de diversas unidades administrativas. Aproximando-se bastante do sistema confederativo, e integrado por órgãos de consultas para política externa comum e para a interpretação dos tratados assinados, além de um juízo conciliador e arbibral, e de órgãos responsáveis pela administração e controle de uma força armada confederada.

Bolivar comungava do pensamento político liberal, idealizava um modelo federalista superior ao Estado nacional centralizado ${ }^{41}$. Contudo, considerava que a tarefa proposta era realisticamente dificil, porém, já fixara diretrizes principais para uma organização que por ventura viesse a ser criada. Assim, a Carta da Jamaica não pregava a unidade política institucional da América ibérica, mas indica a agregação de diversas unidades administrativas como caminho para obter a liberdade junto à metrópole. ${ }^{42}$

\footnotetext{
s9 Santa Aliança era formada por Rússia, Austria, Prussia, França, fundamentava-se no Protocolo de Troppau de 1820, visava defender interesses monárquicos e absolutistas, apoiando medidas contránas as revoluçoes liberais em qualquer parte do território europeu. ARNAUD. Op. cit, p. 309.

to Em seu trecho inicial: Eu desejo, thais do que qualquet outro, ve" formar-se na America a maior naça do mundo, menos por sua extensäo e riqueza do que pela sua liberdade e glóna. Ainda que aspite à pertetya do govertio de minha pátria, não posso persuadir-me de que o Novo Mundo seja, no

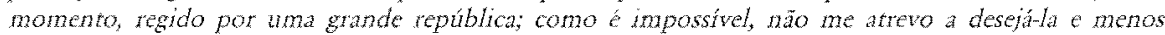
ainda wata monarquia universal da América, porque este projeto, sem ser útil, é também impossivel. Os abusos que atualnente existem não reformatiam e nossa regeneracio seria infutifera. Os Estados americanos tên aecessidade dos cuidados de govenos paternais que curem as chagas e feridas do despotismo dit guema (...). BELLOTO, apud SANTOS, Ricardo Soares Stersi dos. MERCOSUL e arbitmgem intemacional comercial: aspectos gerais e algumas possibilidades, $\mathrm{p} .19$.

"Nadie, quizis, wizoró com más protundidad e insistencia que el Libertador Simón Bolvar la necesidad de fomar en nuestro continente una gran "Nación de Repiblicas" y los peligros de no lograto. VACCHINO, Juan Mario. Esquemas latinoamericanos de integracion: problemas y desarrollos. In Pensamiento lberoamericano, p. 57.
}

12 SANTOS. Op. cit. p. 23-5 
Em 1826, Bolivar planejara e estruturara o Congresso do Panamá. Pretendia com este evento demonstrar e convencer os povos ibero-americanos constituídos por governos livres e Estados independentes, da necessidade de unirem forças para lutar contra inimigos comuns. Os países tinham problemas internos e haviam sido abandonados por outras nações, somente restava a convergência. ${ }^{43}$

Vinha Bolívar manifestando sua vontade para uma América Hispânica em diversas cartas enviadas ao General Santander, e no texto $U m$ Pensamento sobre o Congresso do Panamá. O Libertador idealizava essa comunidade de Estados assentada sobre normas comuns universais, devidamente codificadas, garantidoras dos princípios da liberdade e autodeterminação dos povos, da igualdade e equilíbrio dos Estados e do poder de inserção desta Comunidade nas decisões a serem adotadas pela Sociedade Internacional. ${ }^{44}$

Desejava dessa forma, Bolívar, a Inglaterra integrada à confederação, com intuito de garantir a segurança internacional; em troca, sinalizava para a possibilidade da constituição de uma zona de livre comércio entre os Estados-Membros. Tal situação representava uma contraposição à Santa Aliança è à Doutrina Monrod ${ }^{15}$.

Lembra Ricardo Stersi que, da gestão diplomática do congresso, ficou encarregado o General Santander ${ }^{46}$, contrário a qualquer organização capaz de antagonizar com as forças regionais. Não querendo opor-se abertamente a Bolivar e ao ideal do Congresso, optou por fazer desse Congresso uma miscelânea de interesses diversos. Convidou todos os países, nações, independentemente da inclinação política, assim impediria a formação de uma confederação. ${ }^{47}$

A negociação dos conflitos e a manutenção da paz, objetivos do Congresso perderam-se com a grande Colômbia divida em quatro países, e todas as demais fragmentações na América Central, além da Guerra do Paraguai, e dos EUA contra o México. ${ }^{48}$

\footnotetext{
s. Idem, ibidem.

th Idem, p. 26.

*5 Pata Chomski, a Doutrina Monfoe representava uma simples tentativa do governo norte-americano de afastar em defanitivo a Inglaterra das Américas, é o que se depreende da observaçäo do texto O Maior "Premio" da História, na parte intitulada: Arualizando a Doutrina Monroe, onde o autor analisa a tomada de poder em definitivo por parte das companhias petrolfferas norte-americanas na peninsula arábica e a relegaça dos britânicos a um papel secundáno. CHOMSKY, Noam. Novas e velhas ordens mandiars, p. $237-40$.

4hesidente de Nova Granada atual Colómbia, formada por Nova Granada, Venezuela, Equador e Panamá.

SANTOS. Op cit., p. 268.

4. SEITENFUS, Ricardo. Manual das organizaçóes internacionats, p. 30-5.
} 


\subsection{Novas tratativas, congressos c acordos posteriores}

O México nos anos de $1831,1838,1839$ e 1840, passou a convocar os participantes do Congresso do Panamá para novos congressos, mas nenhum deles se realizou. Entre 1847 e 1848, ocorreu o Segundo Congresso de Lima. Ali se reuniram os países convidados, contudo sem ratificações posteriores dos acordos, tendo sido criada a Confederação dos Estados. No Chile, em 1856, foi assinado um Tratado de Aliança e Assistência Recíproca entre Chile, Equador e Peru. A Monarquia brasileira continuava antagonizando os esforços americanos. ${ }^{49}$

No mesmo ano em Washington foi assinado o Tratado de Aliança e Confederação. Novamente em Lima, 1865, nova fase começa a ser delineada - abandono das idéias confederativas de Bolívar - com o papel fundamental desempenhado pelo argentino Alberdi, e preocupações centradas no comércio, transporte, comunicaçâo e defesa. Nenhum dos pactos e ou tratados anteriores foi ratificado. ${ }^{51}$

\subsection{O Pan-americanismo}

Conforme as observações de Stersi, o fim da ameaça dos colonizadores instala uma nova fase para a América Latina. Os projetos de união polf́tica cedem lugar para as relaçôes intergovernamentai ${ }^{52}$. Em Washington, no ano de 1889, foi instalada a I Conferência Internacional dos Estados Americanos. A ausência das ratificações necessárias transforma a Conferência num fracasso, mas a criação de um escritório permanente para oportunidades comerciais constituía-se numa vitória. Seguiram-se a I Conferência Internacional, as Conferências do México em 1901, Rio de Janeiro em 1903, Buenos Aires 1910, quando o escritório comercial permanente transformou-se em União Panamericana.

\footnotetext{
to Item, ibidem.

SANTOS, p. 31-3.

${ }^{3}$ Peter Nehenkis Jr., em sua obra, Latin América: Myth and Realituty, editada em 1964, assim apresentava o problema da unia latino americana: "Amérté Latina, de to conezar a pensat y actuat como potencia continental, no tendrá futuro en el escenaro mundal. En el mundo contemporáneo, formado por bloquer economicos y de poder, no hay lugar para ancronismo politico de las soberanias del café, ef

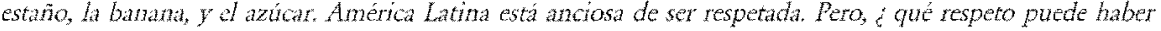
para una estructura politica balcanizada y drvidida por rivalidades menores y rencillas, apenas controlables, que prefiere argumentaciones domesticas a soluciones continentales? Apud, GAY, Gaston de Prat. Politica Intemacional del grupo latinoamericano. Buenos Aires: Abeledo-Perrot, 1967. p.16.

s: SANTOS, p. $33-4$.
} 
Com a eclosão da Primeira Guerra Mundial as reuniões são interrompidas. Após 1919, Woodrow Wilson propõe um pacto nas Américas, semelhante ao que criara a Liga das Nações. Seguiram-se ainda as reuniões de Santiago, em 1923, Havana em 1928, Montevidéu, em 1933, e Lima, em 1938. Neste período, não havia nenhuma disposição dos países americanos encaminharem uma integração de qualquer natureza. Ademais, as diversas e crescentes propostas de integração política não logravam qualquer resultado concreto, apenas representavam um esforço diplomático de aproximação entres os Estados do Continente americano.

\subsection{Organismos, tratados e associações: elementos recentes da} integração latino-americana

No período posterior a Segunda Guerra Mundial, começaram a surgir novas vertentes interessadas de fato numa integração, não mais do tipo política, mas que pudesse implementar o desenvolvimento econômico entre os países americanos, principalmente entre os Estados latinos.

Em 1948, ocorre a Conferência de Bogotá, como a finalidade de promover a solidariedade americana, assegurar a soberania e a cooperação econômica entre os Estados, criara Organização dos Estados Americanos (OEA). Em 1957, realizout-se a Conferência Econômica da OEA, na cidade de Buenos Aires, fundamentada nos estudos da Comissão Econômica das Nações Unidas para a América Latina e Caribe (CEPAL) - nasceu junto com a Comissão Econômica para a Europa das Nações Unidas -, que introduziu o conceito de cooperação regional nos anos cinqüenta, baseado num sistema de preferências comerciais como forma de acelerar o desenvolvimento econômico. Os estudos realizados pela CEPAL constataram inúmeros problemas, dentre eles, a realização de comércio com países desenvolvidos em detrimento da realização de comércio com países fronteiriços. Raul Prebisch, no ambiente CEPAL, defendia a criação de um mercado regional sul-americano, como forma de acelerar o processo de industrialização, situação almejada pela maioria dos governos latino-americanos. ${ }^{53}$

Lembra Oliveira, que até o início do século XX, o pensamento dos cientistas sociais, na América do Sul, era marcado por teorias estrangeiras, que não possibilitavam a busca de respostas adequadas aos problemas locais. A teoria da dependência ousou ao romper com os conceitos

ALMEIDA. Op. cit., p. 63-7. 
estruturais e paradigmas externos, trazendo a lume elementos estruturais ignorados pelos cientistas sociais europeus e norte-americanos. Uma das correntes dependentistas é representada por cientistas sociais ligados à CEPAL ${ }^{54}$

As inovaçôes sugeridas resultaram no Tratado de Montevidéu de 1960, que criou a Associação Latino-Americana de Livre Comércio (ALALC), objetivando a criação de uma Zona de livre comércio e num futuro mais distante um Mercado Comum, assim eliminando barreiras comerciais, promovendo um melhor aproveitamento dos bens produzidos pelos integrantes do Tratado, estimulando as troca entre os integrantes do bloco. Alguns dos instrumentos utilizados para a liberalização comercial eram as listas nacionais de concessão, negociadas a cada ano; as listas comuns reestruturadas a cada período de três anos e os acordos de complementação, furmados bilateralmente entre os integrantes da ALALC, com a possibilidade de estender as vantagens a terceiros integrados ao pacto. $O$ Tratado era ambicioso e pouco flexível, tendo sido prejudicado pelos governos ditatoriais. A estagnação deu origem a um subgrupo andino que formando as bases da Ata de Barahona em 1991, o Pacto Andino, posteriormente Comunidade Andina. ${ }^{55}$

Em 1969, na cidade de Brasília, é assinado o Tratado da Bacia do Prata Argentina, Brasil, Bolívia, Paraguai e Uruguai - para aproveitamento conjunto dos recurso naturais da região ${ }^{56}$. Em 1975, no Panamá é criado o Sistema Econômico Latino-americano (SELA) de cooperação intra-regional.

No ano de 1980, em Montevidéu, é criada a Associação Latino-Americana de Integração (ALADI). Com o retorno de governos civis e da democracia, o Continente iniciou de fato sua integração; a ALADI tinha como objetivo o estabelecimento gradual e progressivo de um mercado comum ${ }^{57}$. Enquanto o escopo principal da ALALC era a eliminação, até 1980, de grande parte das restriçōes comerciais existentes entre os membros, a ALADI pretendia, além de um mercado comum regional, o desenvolvimento do comércio intra-regional, promovendo a regulamentação do comércio recíproco, através de acordos bilaterais, de complementação econômica e de um estabelecimento gradual de um mercado comum latino-americano. Assim, apresentava uma relativa flexibilidade e um propósito específico que era o de compatibilizar os acordos bilaterais com o novo acordo. Não

54 OLIVEIRA, Odete Maria de. Paradigma da Dependencia. In: BEDIN, Gilmar Antonio et. al. Paradigmas das relaços intemacionais: idealsmo, realismo, dependênca, interdependéncha p. 163 -4.

$\approx$ SOARES, Esther Bueno. Mercosul: desenwolvimento histórico, p. 1540.

in Idem, ibidem.

57 rem, ibidem. 
se pode olvidar de um elemento importante nesta observação, que se refere à conjuntura recessiva da década perdida para os grandes pivôs do desenvolvimento latino-americano: Argentina, Brasil e México. As crises cambiais, financeiras, monetárias não permitiam uma tranqüilidade que possibilitasse a liberalização do comércio regional e assim uma autêntica integração.

\subsection{A integração do Cone-sul: grandes dificuldades a vencer}

Não restam dúvidas sobre a importância da superação ou ao menos da minimização, das diferenças entre Brasil e Argentina no contexto das relações internacionais, para integração ou formação de um bloco regional na América do Sul. A ausência de qualquer dos dois países, representa um demérito para qualquer associação regional local. Ambos possuíam e possuem significativa importância dentro do contexto americano, tanto no que tange a aspectos econômicos, políticos e estratégicos.

As relações Brasil e Argentina ${ }^{58}$ sempre se mantiveram em compasso cauteloso, ambos temiam que o outro assumisse uma posição hegemônica na América do Sul. A interdependência, conforme assinalou Bandeira, era tão forte que acabava por inibir os conflitos, quaisquer que fossem as causas, compelindo-os em meio a tensōes e desconfianças, a empreenderem, periodicamente, esforços comuns para o entendimento e a cooperação. ${ }^{59}$

Certamente, que um dos elementos importantes na integração BrasilArgentina decorre da superação da rivalidade estratégico-militar em relação à questão nuclear. Apesar do relativo fracasso do Programa Nuclear Civil brasileiro, o Programa Paralelo - conduzido pelos militares - demonstrou inovaçôes que indicavam que "[s]ecretamente as Forças Armadas iam percorrendo todos os degraus" para consecução de um artefato nuclear, prostrando os militares argentinos. Estes, contudo, investiram grande numerário no desenvolvimento e pesquisa nuclear, ao final de 1983, obteram condiçóes tecnológicas para o enriquecimento do urânio, e tornaram-se também, capazes de fabricar o artefato nuclear. ${ }^{60}$

\footnotetext{
58 Para uma exaustiva e completa abordagem das relaçóes entre Brasil e Argentina ver: BANDEIRA, Moniz. O cixo Argentina-Brasil: o processo de integraçäo da América Latini.

39 BANDEIRA, Moniz. Estado nacional e politica intemacional na América Latina: a continente nas relaçôes Argentina - Brasil (1930-1992), p. 26.

6. OLIVEIRA, Odete Maria de. A integração bilateral Brasil-Argentina: tecnologia nuclear e Mercosul. In: Rewista Brasicata de Politica Internacional, p. 5-12
} 
A superação da rivalidade iniciou de modo informal, com aproximação dos cientistas argentinos e brasileiros, por intermédio de convites enviados aos pesquisadores e não às instituições. Nos anos setenta algumas personalidades já esboçavam idéias com o intuito de unir os dois programas atômicos, evitando a corrida armamentista. Porém, somente nos anos oitenta o Acordo de Cooperação para o Desenvolvimento e Aplicação dos Usos Pacíficos da Energia Nuclear é firmado ${ }^{6}$; sendo este um passo posterior, de um estudo que aferiu as características de cada um dos programas. $^{62}$

Não se olvide ainda, do sistema hidrográfico da bacia do Prata, que constitui-se em elemento importante dentro do processo de integração regional dos países sul americanos. Este importante sistema fluvial que toca os territórios, argentino, boliviano, brasileiro, paraguaio e uruguaio, por ocasião da construção da barragem de Itaipu, ilustrou as diversas matizes de interesses envolvidos na exploração das águas do rio Paraná.

Caubet relata que entre a decisão brasileira de construir uma barragem no rio Paraná - início do ano de 1960 - e o acordo final que possibilitava a realização do intento - acordo tripartite de 1979 , entre a Argentina, o Brasil e o Paraguai -, decorrem mais de dezenove anos ${ }^{63}$. Ante ao abandono da posição pendular do Paraguai - característica das relações internacionais daquele país, em relação Brasil e Argentina - e a tendência para apoiar o Brasil no caso Itaipu ${ }^{64}$, as discussóes ficaram polarizadas entre o eixo Brasília-Buenos Aires, que ultrapassaram o limite da competitividade e rivalidade para o nível de confrontação e crise. ${ }^{65}$

Lembra Oliveira, que somente a restauração dos regimes democráticos possibilitou a assinatura da Declaração de $\operatorname{Iguaç}^{66}$ que representou um marco histórico, originando a assinatura de vários instrumentos de cooperação econômica, como são a Ata para Integração Brasileiro-Argentina $^{67}$, que institui o Programa de Cooperação Econômica (PICE); o

\footnotetext{
61 Oliveira arrola mais de 26 documentos - tratados, acordos, protocolos, declaracões, convênios -. assinados de 1980 a 1992, referentes a questão nudear entre Argentina e Brasil. OLIVEIRA, Odete Maria de. A integraça nucleat Brast-Argentina: una estratégia comparthata, p. 176-180.

s. Idem, p. 12.4 .

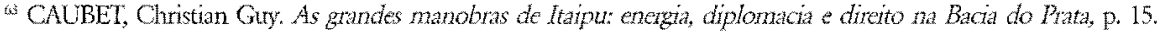

of Idem, p. 13841.

Idem. p. 115.

"Tinha dois objetivos: "[c]riar um Grupo de Trabalho Conjunto de alto nivel presidido pelos Ministros de Relaçôes Exteriores dos dois países, e firmar os compromissos de cooperação nuclear pacifica". OLIVEIRA. A integraçäo bilateral Brasil-Argentina: tecnologia nuclear e Mercosul. In: Revista Brasiletia de Politica Internacional, p.14.

${ }^{57}$ Objetivava criar un espaço económico comum, com a abertura gradual e seletiva dos mercados nacionais dos membros, promovendo o estínulo à complementnção econômica de setores da econômica de Brasil e Argentina.
} 
Tratado de Integração, Cooperação e Desenvolvimento de 198868; além do Estatuto das Empresas Binacionais Brasileiro-Argentinas de 1990, e do Acordo de Complementação Económica-ACE-14 que regulou as relaçôes econômicas sociais entre Brasil e Argentina de 1991/1994.

Ainda, o Tratado de Assunção de 1991, visando a constituição do Mercado Comum do Cone Sul, seguido do Protocolo de Brasília de 1991, da Carta de Canela de 1992, do Cronograma de Las Leñas de 1992, e do Protocolo de Ouro Preto de 1994, dentre outros. ${ }^{69}$

No ambiente latino-americano são criados a Comunidade do Caribe (CARICOM) em 1989; o Mercado Comum Centro Americano (MCCA) e o Plano de Ação Econômico da América Central (PAECA) de 1990 que reúne Panamá, Costa Rica, Honduras, Guatemala, El Salvador, Nicarágua; e o Grupo Andino de 1991, que possui uma zona de livre comércio desde 1992, formado por Peru, Colômbia, Equador, Bolívia, e Venezuela. ${ }^{70}$

A Iniciativa para as Américas (IPA) assinado em Washington em 1991 - Tratado Jardim das Rosas ou 4+1 -, de iniciativa do Presidente Bush, pretende uma zona de livre comércio do Alaska à Terra do Fogo conhecida como Área Hemisferica de Livre Comércio (AHLC); em 1992, o North American Free Trade Agreement (NAFTA), com pretensões de estender seu poder por todo o continente. ${ }^{71}$

Todos as datas e eventos arrolados são elementos considerados como manifestações da vontade de realizar uma integração latina. Apesar de transparecerem uma ausência de compromisso ou uma falta de credibilidade nos próprios fins de uma integração, são as bases históricas que vão constituir o objetivo futuro de uma América Latina unida.

\section{Elementos distintivos}

Afirmar que há uma só grande diferença entre os processos europeus de regionalização e os processos latino-americanos é incorrer em equivoco, já que muitos são os fatores que impulsionaram a formação dos dois blocos.

\footnotetext{
:Rra a manifestaçáo do desejo de constituir, no prazo máximo de 10 anos, um espaço econômico comum, por meio da liberalização integral do intercambio recíproco, para tanto celebraram 24 protocolos especíicos, en diversas áreas.

(2) SOARES, p. 1540 .

7) Idem, Ibidem.

"dem, lbidem.
} 
Porém, é inegável a existência de algumas diferenças nodais entre ambos os processos que, em última análise, influenciam todas as posturas adotadas por estes e aqueles países. A primeiras destas diferenças centra-se no fato de que na formação do bloco europeu, o elemento político era mais significante ou tão significante quanto o elemento econômico. $\mathrm{Na}$ América Latina, de modo contrário, o elemento político nunca foi mais vigoroso que o econômico para fins de integração entre países.

Em resumo, pode-se dizer que, enquanto o processo de constituição das Comunidades Européias esteve particularmente centrado ou condicionado por elementos de natureza política, o desencadeamento da integração latino-americana foi, "[a]o nível teórico, produto do questionamento da teoria clássica do comércio entre os países industrializados e os paises produtores de matérias-primas; e foi ao nível prático imediato, produto dos efeitos negativos que o comércio internacional teve a partir dos anos 50 para as economias da região". 72

$O$ desenvolvimento da cooperação regional no passado recente da América Latina estava ligado a reestruturação das relações econômicas internacionais. $O$ pronunciamento a partir de posições conjuntas no âmbito da CEPAL, o papel determinante na criação da Conferência das Naçöes Unidas sobre Comércio e Desenvolvimento (UNCTAD), além das propostas dos países latino-americanos à elaboração de uma carta dos direitos económicos e um código de conduta transnacional, deixavam transparecer tal entendimento.

De modo contrário, toda carga histórica conflitiva que a Europa carrega, foi como é, determinante quando da tomada de qualquer decisão no contexto plurilateral; influenciou a formação das Comunidades Européias e posteriormente a União. De modo algum o elemento econômico é menos importante, contudo, divide o grau de importância com o elemento político.

As duas conflagrações mundiais, a ameaça nuclear e a guerra fria inculcaram um aparente terror ${ }^{73}$ entre as nações européias, que viveram um longo período sob a égide do medo da guerra total. O fortalecimento político seria o passo mais importante para em tese manter seu espaço geopolítico, bem como, sua importância nas decisões tomadas no espaço internacional.

\footnotetext{
BIEBER. Op. cit, p. 30 .

7 A aparencia de teror é destacada em função das teses Aron, ao entender que EUA e URSS serapre prostraram-se contra a guetra total ou mesmo o holocausto atómico, "[o]s reputam inimigos, apesar do seu parentesco, opinião que näo é falsa mas que tende a ignorar o aspecto de solidariedade inconsciente ou implicita que qualifica a hostilidade". ARON, Raymond. Paz e guerra entre as naçós, p.657.
} 
Por exemplo, poderia parecer despropositada a reunião dos Estados-membros da União Européia ao discutirem a situação da sucessão política interna de um dos seus membros, quando no primeiro semestre do ano 2000 , o Partido da Liberdade - que congrega a direita radical; marcado por posições neonazistas - obteve cerca de $30 \%$ dos votos dos austríacos, condição de segundo partido mais votado, ficando apto a formar com os conservadores um governo de coalizão. Ou seja, decorridos mais de cinqüenta anos do fim da Segunda Guerra Mundial, o combate às teses nazi-fascistas continua pautando a ação dos governos democráticos e da sociedade européia.

No contexto latino-americano, logo no do Mercosul, é inegável que de forma explicita ou mimetizada, o poder dos norte-americanos sempre operou interferências inconcebíveis; não seria ousado afirmar que não há um só país latino-americano que tenha ficado livre daquela ingerência ${ }^{74}$.

Apesar da Carta das Nações Unidas ${ }^{75}$ há muito ter consagrado o princípio da não intervenção com um importante suporte para as relações internacionais e, da Assembléia Geral, utilizando-se de Resoluções, ter ampliado o entendimento concernente ao princípio ${ }^{76}$, dando contornos claros e significativos, pouco se alterou no cenário latino-americano.

Tal situação poderia ser um elemento motivador para um trabalho conjunto de rechaçamento deste comportamento, havendo, portanto, um motivador político para os latino-americanos reconhecerem a necessidade de estabelecer vínculos mais estreitos de fortalecimento conjunto.

Apesar destes fatos terem sido amplamente trabalhados dentro da academia, tendo sido concebidas teorias e teses sobre o tema, jamais aqueles fatos - que demonstravam o poderio norte-americano imiscuindo-se na 'vida' da maioria dos Estados latino-americanos -, conseguiram obter uma condição de unanimidade ou de importância que lhes assegurassem a observação e legitimação, a ponto de tornarem-se bandeiras não somente dos

\footnotetext{
A expressäo: "quintal norte americano", referindo-se a América Central, tem sua razão em existir.

2 Art. 2" \$ 4. - "Los miembros de la Organización, en sus relaciones internacionales, se abstendrán de recurrir a la amenza o al uso de la fuerza contra la integridad territorial o la independencia politica de cualquier Estado de cualquier Estado, o en chalquier otra forma incompatible con los propósitos de las Naciones Unidas."

Th Resoluça $n . " 2113(X X)$ de dezembro de 1965 , declara a inadmissibilidade da intervenção nos assuntos donésticos de Estados e a proteça da sua soberania; Resoluçáo n. $2565(\mathrm{XXV})$ de outubro de 1970, relativa às relaçōes e cooperação entre Estados, considerara intervenção, qualquer forma de ingerência ou ameaça atentatória a personalidade do Estado, ou de seus elementos políticos, económicos e culturais, vedando o uso de medidas econômicas, coatoras, e a otganização, fomento, instigação de ativiklades armadas terroristas com objetivo de alterar o regine de outro Estado; Resolugao n. $36 / 103$ de dezembro de 1981 .
} 
movimentos de revolucionários ou de simples resistência, mas sim um mote de político latino-americano.

Um importante fato político foi a condenação dos EUA perante a Corte Internacional de Justiça (CII) no "Case concerning the military and paramilitary activities in and against Nicaragua - Nicaragua v. United States of America" na data de 27 de Junho $1986^{77}$. Quando ficou amplamente documentada a postura norte-americana em relação aos países latinos, notadamente em relação à Nicarágua. ${ }^{78}$

Hoje, lembra Lowenthal, cinco grandes mudanças internacionais ocasionaram transformaçōes no contexto das relações entre Estados Unidos e América Latina: i) o desmoronamento da União Soviética; ii) o fim da guerra fria e a afirmação dos Estados Unidos com potência mundial dinâmica; iii) a legitimação generalizada da democracia política e do livre mercado; iv) a propagação do poder econômico para a Europa e Ásia; v) a reestruturação básica da economia mundial. ${ }^{79}$

Um segundo elemento que pode ser apontado como importante é que traça uma distinção significativa entre os processos de integração da União Européia e do Mercosul refere-se ao procedimento adotado na tomada de decisões.

É um dos fatores que pode ser considerado como decisivo na dinamização da integração regional européia e o que se refere a supranacionalidade. Este elemento é um catalizador importante na medida que torna a política integracionista independente das contingências políticas internas de cada Estado-membro. Ocorre, portanto, uma descentralização do poder dos Estados, que se abstêm de atuar seus objetivos políticos, em direção a uma centralização coordenada pelos órgãos ou instituições supranacionais que impulsionam a política do bloco. Interessante notar que o conceito de supranacionalidade recebeu status normativo já em 1951, com o Tratado de Paris de criou a CECA.

\footnotetext{
77 Résumé des arrêts, avis consultaifs et ordonnances. Affaire des Activités mîlitaires et paramilitaires au Nicaragua et contre celui-ci (Nicaragua c. Etats-Unis d'Amérique) [fond] Arrêt du 27 juin 1986. Sítio da Corte Internacional de Justiça: http:/ wwwicj-cij.org .

7\% A agravante neste caso refere-se ao desfecho, qual seja, o não acatamento por parte dos EUA da decisão da CII, praticando ato llicito em funço do artigo 94 da Carta das Naçöes Unidas. Na busca da "execuçăo forçada" da sentença por parte do Conselho de Segurança das Naçóes Unidas, este viu-se "engessado" pelo fato dos Estado Unidos ser membro do Conselho, sendo necessário que ou os Estados Unidos votasse contra si, ou renunciasse seu voto. REZEK, Jose Funcisco. Diteto internacio nal público: curso etementarp.368.

79 LOWENTHAL, Abraham F. Os Estados Unidos e a América Latina na década de 90 : interesses e políicas norte-americanas em mudança em um novo mundo, p. 147.
} 
Como lembra Oliveira, os elementos essenciais ao pressuposto da supranacionalidade são: a) o reconhecimento da existência de um interesse comum e de valores comuns; b) a criação de um poder efetivo ao serviço destes interesses; c) a autonomia deste poder; d) a imediatidade do exercício de poder e sua imperatividade. Estes pressupostos devem necessariamente ser associados à existência de três condições básicas, são elas: a) os Estados integrantes tenham transferido o exercício de competências soberanas à organização; b) que a organização seja independente de seus membros; c) que as declarações de vontade da organização possam ser emitidas independentemente das adesões dos Estados e que produzam diretamente efeitos sobre esses Estados e pessoas. ${ }^{80}$

O sistema adotado no Mercosul difere significativamente do modelo europeu. E esta questão é sempre referida com um problema central no processo de integração. Tendo sido considerada como um entrave à ampliação, ao crescimento e amadurecimento do bloco. Muitos estudiosos defendem que desde logo deveriam ser criados órgãos comunitários com autonomia para conduzir o processo de integração com mais afinco. Contudo, tal postura é inaceitável para os membros, a idéia de soberania permeia o discurso dos que defendem as idéias intergovernamentais, $e$ aquela é absoluta, indivisível, imprescritível e inalienável.

Almeida entende que opção por estruturas do tipo intergovernamental, submetidas a regras de unanimidade, foi no entender dos países membros, a mais adequada à etapa atual do processo integracionista em escala sub-regional, já que não parece necessária a adoção de tal medida para implementação das ações relacionadas a livre-circulação de bens e serviços e a instituição da tarifa externa comum. ${ }^{81}$

\section{Elementos de aproximação}

Do ponto de vista histórico, observam-se diferenças substanciais entre a formação de blocos de cooperação conduzidos na América Latina com - Mercosul e a na Europa com a União Européia. Contudo, há confluências que se destacam é que podem ser apontadas:

i) o período em que surge como vontade organizada;

ii) os objetivos desenvolvimentistas;

3) OLIVERA. União Europeia: processos de integragão e mutaço, p. 689.

ALMEIDA. Op. cit, p. 1301. 
iii) reflexos de um momento político internacional - evitar a expansão do sistema bipolar na forma de alinhados não alinhados;

iv) fazer frente ao poder político e econômico dos Estados Unidos.

A primeira delas refere-se ao periodo em que ganha força o ideal integracionistas, tanto na Europa como na América Latina, na segunda metade dos anos quarenta e toda década seguinte. Neste período a cooperação deixa à especulação para concretizar-se na forma de tratados ou acordos. Em relação à observação dos mesmos e cumprimento dos prazos as diferenças são muitas. Apesar do Mercosul não ter formalmente iniciado neste período, não se pode negar que todas as bases do diversos processos de regionalização presentes na América Latina começaram de uma forma mais consistente no período assinalado.

O seguinte elemento, apontado como similar nos processos analisados é a opção pela integração como reflexo de teses desenvolvimentistas, que vislumbravam:

i) uma maior eficiência na produção, pela especialização crescente dos agentes econômicos;

ii) altos níveis de produção pelo maior aproveitamento das economias de escala permitidas pela ampliação de mercado;

iii) melhor posição de barganha no plano internacional, em virtude das dimensões ampliadas da nova área, melhorando os termos de intercâmbio;

iv) mudanças positivas na eficiência econômica dos agentes;

v) transformação na qualidade e quantidade dos fatores de produçào, avanço tecnológico;

vi) mobilidade de fatores através das fronteiras entre os paises membros, permitindo alocação otimizada de recursos;

vii) coordenação de políticas monetárias e fiscais num sentido teoricamente mais racional, já subordinadas a uma lógica impessoal não à pressão de grupos setoriais ou correntes politicamente influentes em escala nacional;

viii) os objetivos do pleno emprego, altas taxas de crescimento econômico e de uma melhor distribuição de renda tornar-se-iam metas comuns. ${ }^{82}$

Em resumo, os processos integracionistas buscam melhorar as condições econômicas dos membros.

\footnotetext{
2 Os tópicos arrolados săo considerados vantagens possiveis que o Brasil teria se desenvolvesse uma Zona de Livre Comércio, logo adaptado para o presente texto, já que externalidades positivas de qualquer processo integracionista. Idern, p. 204.
} 
O terceiro elemento apontado como particular aos dois processos é decorrente do momento político internacional caracterizado pela bipolaridade onde muitos dos não alinhados buscavam uma independência geopolítica, criando condiçôes e ganhando força para marcar um espaço no contexto internacional criando sistemas continentais de defesa - Tratado Interamericano de Assistência Recíproca de 1947 e Comunidade Européia de Defesa de 1952.

Enquanto os soviéticos provocavam desconfiança dos Europeus, pelo fato de estarem no centro da Europa bem como na Europa Oriental. Os norte-americanos com sua postura pouco amistosa - big stick - produziam um insegurança constante para os países latino-americanos, o que convencionou-se chamar de imperialismo. ${ }^{83}$

Foi em meio ao desenrolar da Guerra da Coréia em 1952, que se elaborou às pressas, um projeto de defesa comum para Europa, a chamada Comunidade Européia de Defesa (CED). Não logrou êxito possivelmente pela aspiração ambiciosa de colocar todas as forças armadas sob o mando de um poder supranacional. O projeto da constituição da CED ficou conhecido como "Plano Beyen" ${ }^{",}$, sua estrutura foi aproveitada como base para o Tratado de Roma de 1955, já que apesar de ser um acordo setorial haviam alguns dispositivos básicos secundários que preparavam um mecanismo paralelo de integração econômica. ${ }^{85}$

Apesar do Tratado Interamericano de Assistência Recíproca (TIAR) anteceder o Mercosul, não se pode negar que o assunto "defesa conjunta" sempre interessou os latino-americanos e em especial Argentina e Brasil.

\footnotetext{
* Algumas demonstraçoes do imperialismo norte-americano podem ser observadas em intervençoes ocorridas desde a década de cinqüenta na América Latina, em que predominantemente houve utilizaçào de força militar de forma direta ou indireta, assim: Guatemala (1952), República Dominicana (1956), Cuba (1961), Chile por subversāo (1973), Argentina/Malvinas (1982), Granada (1983), Panamá (1989, com o pretexto de que o ex-presidente e Comandante Chefe do Exército General Noriega estava utilizando o Estado para canalizar drogas para os EUA), Nicarágua (mais de dez anos financiando os contra-revolucionários e utilizando a própria força, com ataques diretos nos anos de 1983 e 1984, Puerte Sandino (set/1983), Corinto (out/1983), Base Naval Potosi (jan/1984), San Juan del Sur (mar/ 1984), ataque a barcos patrulheiros em Puerto Sandino (mar/1984), San Juan del Norte (abr/1984)\}. MOREIRA Adriano. Teoria da Relaçóes Internacionais. p.150-1. CASTRO, Paulo Jorge Canelas. Da näo intervença à intervenço ? ( o novimento do pândulo jurdico perante as necessidades da Comunidade Intemacional). p. 310. CI - Résumé des arrêts, avis consultatifs et ordonnances. Affaire des Activités militaires et paramilitaires an Nicangua et contre celuirei (Nicaragua c. Etats-Unis d'Amérique) [fond] Arrêt du 27 juin 1986. Sentença CI.J. Nicarágua v. EUA. Sítio da Corte Internacional de Justiģa : http: /wwicicilorg

\& Beyen refere-se ao nome do Ministro holandes de assuntos exteriores que trabalhou ativamente na preparaça da CED.
}

"TAMAMES Op. cit., p. 40-1 
O ultimo dos elementos apontados como objetivo do processo de integração europeu e do latino americano é o de fazer frente ao poder político e econômico dos EUA.

Neste sentido, terminada a Segunda Guerra Mundial os Estados Unidos possuíam cerca de metade da riqueza do mundo - produção industrial quase quadruplicou em escala durante a fase beligerante -, tinham o maior poder militar, segurança sem precedentes e os inimigos distantes. Dominavam ambos os oceanos, as regiōes mais ricas, as maiores reservas energéticas do mundo e os recursos críticos. ${ }^{86}$

Logo nos estágios iniciais da Segunda Guerra Mundial, planejadores norte-americanos observavam que estariam em posição de organizar grande parte do mundo. No período de 1934 a 1945, amplos estudos sobre o mundo pós-guerra foram trabalhados pelo Ministério das Relações Exteriores, que reuniu círculos financeiros e corporativos internacionalmente orientados e planejadores do Departamento de Estado. ${ }^{87}$

Chomski lembra que foi o um projeto que recebia o nome de "grande área", formando uma economia mundial integrada que satisfaria as necessidades da economia norte-americana e lhe forneceria "[o] campo de ação necessário a fim de sobreviver sem maiores reajustamentos" - ou seja, sem a modificação da distribuição doméstica de poder, riqueza, propriedade e controle.

Como referido anteriormente, os países latinos não souberam aproveitar estes elementos como um catalizador do processo integracionista, libertador e desligado de situações particulares ocasionais. Ainda, especificamente em relação à Europa, o passado reverberará em toda a trajetória política posterior, logo, nas ações buscando compor os litígios profundos.

A América Latina, bem como os membros do Mercosul, não teve o mesmo destino. As conflagrações neste continente tiveram uma repercussão menor - apesar de sangrentas e dolorosas -, e não poderiam ser considerados determinantes para uma união de qualquer natureza. Porém o dado comum aqui se refere aos sistemas de dominação econômico político - definidos em ordem temporal crescente como mercantilismo, colonialismo e imperialismo - levados a efeito por governo de países centrais, notadamente em relação ao imperialismo norte-americano.

\footnotetext{
CHOMSKI. Op. cit, p. 109.

Idem, p. $10 \%, 10$

Idem, p, 110 .
} 
Enfim, os elementos apresentados possibilitam observar uma semelhança muito acentuada nas motivações que conduziram ambos os processos de integração, logo surgiria a indagação, por que um dos processos conseguiu centralizar-se sobre um só bloco, enquanto o outro processo fragmentou-se, e dentro destas fragmentações em de cada processo subregionalizado manteve-se pouco operante?

Certamente que o elemento diferenciador entre a confluência de forças no âmbito europeu e no latino-americano é marcadamente muito forte, assim um processo embasado sobre objetivos políticos diverge em essência de um fundado em objetivos unicamente econômicos. Aspectos culturais, políticos em sentido estrito, sociais, filosóficos não podem ser desconsiderados, contudo o diferencial mais significativo transparece ser o político conforme anteriormente indicado.

\section{Conclusão}

Do ponto de vista político internacional, a integração corresponde a um processo ou estado onde diversas nações, de diferentes nacionalidades, decidem formar um grupo regional. Os objetivos almejados neste processo podem ser os mais variados; contemporaneamente o econômico tem sido manifestado de modo mais significativo.

O regionalismo, tendo sido neste caso o instrumento de implementação do crescimento econômico, tentando fazer frente ao fenômeno da mundialização dos mercados, com a proteção dos mercados regionais. Tanto América Latina como Europa apresentam um rico e antigo histórico de antecedentes em relação à tentativa de formação de unidades de integração; obviamente apresentado algumas aproximações e muitas diferenças.

A observação dos fatos marcantes no decorrer do tempo aponta uma similitude no desejo de formação de grandes confederações, culminado com coletividades de integração ou cooperação. Ainda, elementos de aproximação demonstram particulares semelhanças entre os movimentos analisados, como as relacionadas ao período em que surgem como vontade organizada; em relação aos objetivos desenvolvimentistas; em relação aos reflexos de um momento político internacional - evitar a expansão do sistema bipolar na forma de alinhados não alinhados -; e a de fazer frente ao poder político e econômico dos Estados Unidos. 
Os dados compilados não permitem estabelecer um juízo definitivo sobre os motivos pelos quais os processos de integração União Européia e Mercosul são tão dispares em seus resultados atuais. Contudo, num juízo parcial e inconcluso é possível eleger elementos que por sua natureza ampla possam abarcar importantes causas dessas evoluções, contudo não referidos, além de satisfazer minimamente o questionamento introdutório.

Assim, enquanto na formação do bloco europeu, o elemento político mostrou-se mais significativo que o elemento econômico, na América Latina, o elemento político nunca foi mais vigoroso que o econômico para fins de integração entre seus países, apesar de terem existido motivos para a formação ganhar tonalidades mais política. Podendo ser apontado com motivador da diferença de grau de evolução entre os processos.

A alegação em relação ao instrumento de empuxo supranacional como motivador da integração não deixa de ser relevante, porém incluído no elemento maior que é o da construção de um fenômeno político capaz de unir sobre sua regência todos os elementos de uma integração regional.

Enfim, não restam dúvidas que os elementos históricos significativos presentes no continente europeu - como se estivessem constantemente repetindo a máxima de Santayana: "os que não se podem lembrar da experiência estão condenados a repeti-la" -deram nascimento a um fenômeno amplo que acabou por formar uma das expressões políticas mais notáveis do pensamento humano nos últimos tempos que chamamos de União Européia.

\section{BIBLIOGRAFIA}

ALMEIDA, Paulo Roberto. O MERCOSUL no contexto regional e internacional. São Paulo: Aduaneiras, 1993.

AMIN, Samir. Re-reading the Postwar Period: An Intellectual Itinerary. Trad. Michael Wolfers. New York: Monthly Review, 1994.

ARNAUD, Vicente Guillermo. Mercosur - Unión Europea, Nafta y los procesos de integración regional. Buenos Aires: Abeledo-Perrot, 1996. ARON, Raymond. Paz e guerta entre as naçōes. Trad. Sérgio Bath. Brasilia: UnB, 1986. BANDEIRA, Moniz. O eixo Argentina-Brasil: o processo de integração da América Latina. Brasília: Universidade de Brasília, 1987.

- Estado nacional e politica internacional na América Latina: o continente nas relações Argentina - Brasil (1930-1992).2. ed. São Paulo: Ensaio, 1995. 
BIEBER, León E. Paralelos e diferenças na conformação de blocos de integração regional na Europa e na América Latina. In: O Mercosul e a Comunidade Européia: uma abordagem comparativa. PLÁ, Juan Algorta (org.). Porto Alegre: UFRGS, 1994.

BOLIVAR, Simón. Discurso proferido junto a "Sociedad Patriótica de Caracas" em. 3 de Junho de 1811. http://wekker.seagull.net/discursos.html; CARR, Edward Hallett. Vinte anos de crise: 1919-1939: uma introdução ao estudo das relaçôes internacionais. Trad. Luiz Alberto Figueiredo Machado. Brasília: UnB, 1981.

CASELLA, Paulo Borba. Comunidade Européia e seu ordenamento jurídico. São Paulo: LTr, 1994.

CASTRO, Paulo Jorge Canelas. Da não intervenção à intervenção? (o movimento do pêndulo jurídico perante as necessidades da Comunidade Internacional). Coimbra: BFDUC, 1995, V. LXXI.

CAUBET, Christian Guy. As grandes manobras de Itaipu: energia, diplomacia e direito na Bacia do Prata. São Paulo: Acadêmica, 1989.

CHOMSKY, Noam. Novas e velhas ordens mundiais. Trad. Paulo Roberto Coutinho. São Paulo: Scritta, 1996.

DUROSELLE, Jean Baptiste. A Europa de 1815 aos nossos dias: vida política e relaçôes internacionais. Trad. Olívia Krähenbühl. 2. ed. São Paulo: Pioneira, 1985.

EUROPA passo a passo: cronologia da comunidade européia. Luxemburgo: Oficina das publicações oficiais das Comunidades Européias, 1983 .

GAY, Gaston de Prat. Politica internacional del grupo latinoamericano. Buenos Aires: Abeledo-Perrot, 1967.

HONRUBIA, Victoria Abellán. COSTA, Blanca Vilà (org,). Lecciones de Derecho Comunitario Europeo. 2. ed. Barcelona: Ariel, 1994.

JAEGER JUNIOR, Augusto. Mercosul e a livre circulação de pessoas. Florianópolis, 1999. Dissertação de Mestrado. Universidade Federal de Santa Catarina.

KANT, Immanuel. À paz perpétua. Trad. Marcos Antônio A. Zingano. Porto Alegre: L\&PM, 1989.

LOWENTHAL, Abraham F. Os Estados Unidos e a América Latina na década de 90: interesses e políticas norte-americanas em mudança em um novo mundo. Política Externa, v. 1, n. 3, dez./jan./fev. 1992-93.

MANDEL, Ernest. O significado da segunda guerra mundial. Trad. Lólio 
Lourenço de Oliveira. São Paulo: Ática, 1989.

MOREIRA Adriano. Teoria das relaçóes internacionais. Coimbra: Almedina, 1996.

OLIVEIRA, Maria Odete de. A integração nucleat Brasil-Argentina: uma estratégia compartilhada. Florianópolis: UFSC, 1996.

- A integração bilateral Brasil-Argentina: tecnologia nuclear e Mercosul. In: Revista Brasileira de Política Internacional. Rio de Janeiro: 1958-1992; Brasília: 1993-. Ano 41, n.1, p. 5-23, 1998.

. União Européia: processos de integração e mutação. Curitiba: Juruá, 1999.

. Paradigma da Dependência. In: BEDIN, Gilmar Antonio. et. al. Paradigmas das relações internacionais: idealismo, realismo, dependência, interdependência. Ijuí: UNIJUí, 2000, p. 159-243.

RÉSUMÉ des arrêts, avis consultatifs et ordonnances. Affaire des Activités militaires et paramilitaires au Nicaragua et contre celui-ci (Nicaragua c. États-Unis d'Amérique) [fond] Arrêt du 27 juin 1986. Sítio da CIJ : http:/ /www.icj-cij.org.

REZEK, José Francisco. Direito internacional público: curso elementar. 5. ed. São Paulo: Saraiva, 1995.

SANTOS, Ricardo Soares Stersi dos. MERCOSUL e arbitragem internacional comercial: aspectos gerais e algumas possibilidades. Belo Horizonte: Del Rey, 1997.

SEITENFUS, Ricardo. Manual das organizações internacionais. Porto Alegre: Livraria do Advogado, 1997.

SOARES, Esther Bueno. Mercosul: desenvolvimento histórico. São Paulo: Oliveira Mendes, 1997.

TAMAMES, Ramón. La Unión Europea. Madrid: Alianza, 1994.

THORSTENSEN, Vera. Comunidade Européia: a construção de uma potência econômica. São Paulo: Brasiliense, 1992.

VACCHINO, Juan Mario. Esquemas latinoamericanos de integración: problemas y desarrollos. Pensamiento Iberoamericano, n. 15, ene./jun. 1989. 